\title{
Perpetrators and victims: Austrian economists under the Nazis
}

\section{Reinhard Neck ${ }^{1}$}

Published online: 13 May 2019

(c) The Author(s) 2019

\begin{abstract}
This paper reports on the preliminary results of a research project (supported by the Oesterreichische Nationalbank) about Austrian economists under the Nazi regime from 1938 to 1945 . The biographies of nearly 200 economists were collected who had close relations to Austria and who were affected in some way or another by the politics of the Third Reich: some as perpetrators, followers or opportunists, others as victims who were persecuted, forced to emigrate or who even lost their lives. To illustrate the diverse fate of Austrian economists after the Anschluss, a brief account is given of three economists who belonged to different economic "schools" and who were affected by the Nazi regime in very different ways: Friedrich Gottl-Ottlilienfeld, an NS party member and adherent of the German Historical School; Friedrich Otto Hertz, a sociologist and economist, who was forced into emigration twice; and Karl Schlesinger, a banker with remarkable theoretical contributions to economics who committed suicide on the day the German Wehrmacht invaded Austria.
\end{abstract}

Keywords Economists $\cdot$ Biography $\cdot$ History of economics $\cdot$ Austria $\cdot$ Twentieth century · Nazi Germany

\section{JEL Classification B31}

\section{Motivation}

The period of 1938-1945, when Austria was part of "Greater Germany", the Third Reich, was certainly a most horrible time for all those who despised Nazi ideology and politics. This is especially true for those Austrian scientists who belonged to the large group of people persecuted by the Nazis for "racial", political or other reasons. This period also contributed to the intellectual demise of Austrian academia, which

Reinhard Neck

reinhard.neck@aau.at

1 Department of Economics, Alpen-Adria-Universität Klagenfurt, Universitätsstraße 65-67, 9020 Klagenfurt, Austria 
had already started at the end of the Habsburg monarchy, continued in the First Republic with a lack of recognition by its right-wing governments and intensified under the Dollfuss-Schuschnigg dictatorship ("Austrofascism" or "Ständestaat"). However, the emergence of the Nazi regime brought about an even more devastating effect for science in Austria. The persecution of "Jewish"1 academics started immediately the Nazis came to power (the Anschluss) on March 12, 1938, already prepared by (officially illegal) Austrian Nazi party officials and supporters. While the terror of the new rulers directed at the "Jews" and other minorities was prepared and approved of by too many Austrians, persecution intensified still further on the arrival of the SS and the Secret State Police (Gestapo) following the Anschluss.

Among academics, doctors and lawyers were especially victimized because of the relatively large numbers of "Jews" in these professions. Economists proper were but a small group as there was no degree programme in this field; those studying economics had to take a degree in law or political science. Nevertheless, there were a few hundred people trained in economics in Austria in the 1930s, in academia, public administration and business. Most (but not all) of those with scientific interests were members of the Austrian Economic Association (Nationalökonomische Gesellschaft, NÖG), which had been founded after World War I following in the footsteps of a similar organization in the Habsburg Monarchy. Lionel Robbins (1971, p. 91) wrote the following about the NÖG:

[...] on the morrow of the Anschluss when, to his eternal shame, Hans Mayer, the senior Professor of Economics in the University of Menger, Wieser and Böhm-Bawerk, whom I myself had more than once heard denouncing Hitler and all his works, instead of closing it down as he could honourably have done, expelled the Jewish members from the famous Nationalökonomische Gesellschaft of which he was president.

It was the opinion of the writer of this paper, when president of the NÖG, that it constitutes a moral obligation for the organization to deal with the fate of Austrian economists under the Third Reich. He therefore applied to the Jubiläumsfonds of the OeNB (Oesterreichische Nationalbank, the Austrian central bank) for a research project entitled "Austrian Economists during the NS period", which was funded for the period 2016-2019 and is still work in progress at the time of writing. This paper reports on some preliminary results of this research project on Austrian economists under the Nazi regime from 1938 to 1945 . The final results are planned to be published in a book in German (Neck forthcoming), including contributions by Theodor Venus and Hansjörg Klausinger, who also worked on the project.

\footnotetext{
1 The notion of "Jew" and "Jewish" as used by the Nazis, not defining the persons concerned by their religion but by the Nazi notion of "race", will be used here as a token to signify those people persecuted for anti-Semitic reasons. Of course, this absurd use of the words does not in any way signify consent with that anti-Semitic ideology.
} 


\section{Economic schools and ideologies: Was there an "NS Economics"?}

In the project, we collected biographies of economists who had close relations to Austria and who were affected in some way or another by the politics of the Third Reich: some as perpetrators, followers or opportunists, others as victims who were persecuted, forced to emigrate or who even lost their lives. An initial methodological problem was how to select who to include. From the beginning, it was clear to us that we wanted to obtain as comprehensive a picture as possible of those who could be labelled "Austrian economists" and who had been "affected" by the Nazi regime in the broadest sense of the word. Therefore, we included both those who complied with Nazi ideology and those who were opposed to it (and mostly suffered from the Nazis). As for the label "Austrian", we included everybody who spent either their formative years or an important part of their professional lives in the Republic of Austria. "Economists", in turn, were those who pursued theoretical or applied academic work in economics proper (Volkswirtschaftslehre); those who worked in business or management (Betriebswirtschaftslehre) or in other social sciences (such as sociology) were not included unless their work was relevant for economic theory or policy as well. Members of the NÖG (which could not be verified in many cases as membership lists from the interwar years no longer exist) were always included on the list of "Austrian economists under the Nazis", which now numbers nearly two hundred people.

We are especially interested in the relations between the group of Nazi adherents (devotees, followers, fellow travellers and opportunists) on the one hand and adversaries (emigrants and non-emigrants) on the other in terms of the points of view they took in matters of economics, in particular their positions within a contemporaneous "school of thought". The initial hypothesis was that historicist, romanticist and holistic economists would have clear pro-Nazi tendencies while theoretical, quantitative and individualistic economists would take up anti-Nazi positions. This should correspond to the mostly liberal or socialist ideology of the latter and the conservative (often anti-rationalistic) ideology of the former.

Although the two groups are not distributed evenly across the adherents to the different "schools" of economics that existed in the interwar period, so far, the initial hypothesis could not be corroborated. It seems as though the Austrian economists follow similar patterns to German ones in this respect, which were examined by Janssen (2012) in his ground-breaking study of German economists. For example, Hans Mayer, the only full professor of economics at the University of Vienna who belonged to the Austrian School of Economics (and was president of the NÖG before, during and after the Nazi period), was not only guilty of the act criticized by Lord Robbins above but also presented a text (Rath et al. 1939) at a meeting of the N.S.D. Dozentenbund (the NS Association of University Teachers) in which he argued in favour of applying the methodological instruments and theories of the Marginalist schools to deal with the requirements of the "historic deed of National Socialism" (p. 414) and denounced "liberal" economics as the "primacy of the economy over the life of the people and over politics!". 
Nevertheless some key elements of NS discourses in economic thinking can be identified which are present in the writings of the pro-Nazi economists and absent in those of the anti-Nazis. These include the primacy of politics, the goal of autarky in international economic relations and a positive attitude towards "socialism" (albeit, of course, "German Socialism", not Marxism). While these positions were sometimes also taken by non-NS economists and were certainly enforced by the regime, racist ("völkisch") and anti-Semitic pronouncements were particularly characteristic for hard-core Nazis (although anti-Semitism was more widespread in Austria than in Germany among non-Nazi academics as well, especially on religious grounds). In any case, it would be an exaggeration to speak of a specific NS economics or even an NS economic theory. This explains why it was possible for several Austrian (and German) economists who did not openly oppose the regime to retain their positions at a university or research institute or in public administration.

To illustrate the differing fates of Austrian economists after the Anschluss, we give a brief account of three economists who belonged to different economic "schools" and were affected by the Nazi regime in very different ways. We chose Friedrich von Gottl-Ottlilienfeld as a representative of pro-Nazi economists, Friedrich (Frederick) Otto Hertz as a representative of the emigrants, and Karl (Karol) Schlesinger as a representative of the persecuted victims. The choice of GottlOttlilienfeld instead of the more prominent (and more "Austrian") Othmar Spann is due to the latter's position as both a supporter (as early as the 1920s) and a victim (from 1938 on); moreover, Spann's role as the ideologist of (two versions of) Fascism has already been analysed by Klaus-Jörg Siegfried (1974). Friedrich Hertz can be characterized both as a sociologist and an economist, the present clear distinction between the two areas not having been made in his time. He had to emigrate from the Third Reich twice and his biography has not yet been written in spite of his far-sighted ideas in both economics and sociology. Karl Schlesinger had to pay the highest price for being a "Jew", committing suicide to avoid persecution by the Nazis. He was a member and speaker at meetings of the NÖG and contributed quite important ideas to economic theory.

\section{Friedrich von Gottl-Ottlilienfeld}

Friedrich von Gottl-Ottlilienfeld (often only Gottl) was born in Vienna in 1868, the son of an officer in the Habsburg army who later became a general and was ennobled. He studied in Vienna, Berlin and Heidelberg, where he obtained a doctorate under Karl Knies, a member of the German Historical School of Economics, and a Habilitation in political sciences (Staatswissenschaften). In 1902, he became Associate Professor at the University of Technology in Brno (then Brünn), becoming Full Professor in 1904. In 1908 he moved to the University of Technology in Munich, followed by the newly founded University of Hamburg in 1919, the University of Kiel in 1924 and the Friedrich-Wilhelms-University (now Humboldt University) in Berlin in 1926, where he was director of the Staatswissenschaftliches Seminar and became emeritus in 1936. 
Gottl-Ottlilienfeld can be characterized as being a member of the Historical School. His methodology was influenced by the hermeneutical concept of Verstehen (understanding and interpretation) as developed by Wilhelm Dilthey. Gottl combined the ideas of the Historical School with those of the Conservative Revolution and Romanticism, and later with elements of NS ideology. For example, in his writings after 1933 (von Gottl-Ottlilienfeld 1934a, b, 1940) he used the notion of Volk (people) in his economic texts in a biological sense and introduced other problematic notions. ${ }^{2}$ Gottl also wrote several books and articles on the economic impact of technology in which he expressed his admiration for Henry Ford.

Based on an ontology which justified "scientific" value judgements (cf. Morikawa 2001), Gottl criticized economic theory, especially neoclassical theory and its concept of "value" (cf. von Gottl-Ottlilienfeld 1901, 1923). Against this backdrop, he developed a theory of social entities ("Gebildelehre"), which can be broadly interpreted as taking social groups and other entities as being the fundamental elements of the economy. The theory is of the social holism type, where a hierarchy of social entities ("Gebilde") culminates in the people (Volk). This results in a political programme that can be summarized as the annihilation of "liberalistic-individualistic and Marxist systems" (cf. in particular, von Gottl-Ottlilienfeld 1934a).

Unfortunately, Gottl used an extremely idiosyncratic and complicated language that is very difficult to understand. He was also a prolific and extensive writer, publishing a large number of books (some of them over 1000 pages in length) and articles, which impressed a small but devoted group of disciples, mostly in Germany but some of them also in Japan. It is, however, questionable whether his works were actually read and understood by economists not within the inner circle of his admirers. Haberler (1930) was one of the very few who devoted a critical article to a book by Gottl, and his criticism was devastating, accusing Gottl of masking trivialities with his incomprehensible language. In particular, Gottl's work is virtually void of empirically testable hypotheses.

When the Nazis came to power in Germany, Gottl-although no member of the Nazi party before 1933 - was the recipient of many honours. For example, he became an honorary member of the Deutsche Wirtschaftswissenschaftliche Gesellschaft (a replacement organization for the German Economic Association, Verein für Sozialpolitik, which had been dissolved to prevent its assets from falling into the hands of the Nazis), he received the Goethe medal for art and science (as the first social scientist) and was made a member of the Akademie für Deutsches Recht (founded by Nazi minister and war criminal Hans Frank).

In 1940, after a series of petitions to Nazi officials, Gottl returned to Austria as director of a research institute "for German economics" (Forschungsinstitut für Deutsche Volkswirtschaftslehre) in Graz-Mariatrost. From the point of view of the Nazi administration, this institute was meant to contribute to the study of the economies of Southeast Europe, but Gottl continued working on his "heterodox" economic theories. Although he repeatedly requested that his followers should become

\footnotetext{
${ }^{2}$ For instance, in von Gottl-Ottlilienfeld (1934a) he wrote about "parasitic social entities" which ought to be "extinguished", which were expressions used by the Nazis about the "Jews".
} 
his assistants in this institute, he was essentially the only employee because all of them were drafted for the German army. In Graz, he completed his two-volume opus magnum "Ewige Wirtschaft" (eternal economy).

With the Soviet Red Army on the outskirts of Graz, Gottl escaped to Germany, leaving personal and work-related materials behind. He was not allowed to stay in the cities he wanted to live in and tried to cover up his activities on behalf of the Nazi authorities. During the last years of his life, he had only a few contacts based on his former position in Berlin. Shortly before his 90th birthday, in 1958, Gottl died in Frankfurt am Main.

\section{Friedrich (Frederick) Otto Hertz}

Friedrich Hertz was born in Vienna in 1878 into a "Jewish" family. He studied law and economics at the universities of Vienna and Munich. Already as a student, Hertz became a member of the Social Democrats and published two brief monographs about Social Democratic agrarian policy, one of them critical of Marxist theorist Karl Kautsky and endorsed by revisionist Social Democrat Eduard Bernstein. In 1903, he received a doctorate in economics from the University of Munich. Afterwards, he worked as a writer on economics and editor of a weekly paper. From 1906 to 1913, he was secretary of the Hauptverband der Industrie Österreichs (Federation of Austrian Industries), then from 1913 to 1914 manager of a Swiss insurance company. During World War I, Friedrich Hertz served in the ambulance corps and then in the Scientific Committee for the War Economy at the Ministry of War.

As early as 1904, Hertz published a book of critical essays about theories of race (Hertz 1904) which, under a new title, saw a second and third edition (Hertz 1915/1925). These sociological treatises heavily criticized the anti-Semitic books by Arthur Gobineau, Houston Stewart Chamberlain and other proponents of biologist theories of human races and showed, using a wealth of historical and anthropological material, that the diversity of human races does not imply different abilities and characters. These studies can be seen as early manifestations of a sociological approach to the variety of human beings and were continued in Hertz's later work on nationalism (Hertz 1937, 1944).

In the new Republic of Austria, Hertz was appointed economic advisor by State Chancellor Karl Renner and became Hofrat at the Austrian Federal Chancellery in 1919. Already during the war and in the years following it, he published several monographs about the economic potential of Austria (Hertz 1918, 1921, 1925) which argued in favour of the economic viability of an independent Austria, which at that time was strongly questioned by German nationalists and Social Democrats in Austria. He supported his position with many empirical facts showing that the Austrian industry was at a comparable level to that of Czechoslovakia.

In 1929 Friedrich Hertz was appointed Full Professor of "global economics and sociology" at the University of Halle-Wittenberg in Germany, a position he lost with the rise of Hitler. He was accused of being involved in setting fire to the Reichstag (the German Parliament building) and was dismissed by the Nazi administration in 1933 for being a "Jew, Freemason and pacifist". The main stumbling block for Hertz 
from the point of view of the Nazis was, however, his authorship of the books about nationalism and racism. On the threat of imprisonment in a concentration camp, Hertz and his family emigrated from Germany back to Austria, where he was still allowed to work in public administration and on nationalism (Hertz 1937).

When the Nazis occupied Austria in 1938, Hertz emigrated with family for a second time, this time to London, where he had some contacts from his work at the Austrian Chancellery. He was active in the Austrian emigrants' organizations in the United Kingdom during the Second World War and took up his academic work on nationalism again (Hertz 1944). When the war was over, he tried to return to Austria but could not find support for his endeavours to obtain a professorship there, in spite of his still active friendship with (the now Federal President) Karl Renner.

Probably disappointed with the political situation in Austria, Friedrich (now Frederick) Hertz acquired British citizenship in 1946. Equally disappointed by the infighting in the Social Democrats during his exile, he became a co-founder of the Liberal World Union. Working well into his eighties, he returned to his studies on nationalism (Hertz 1947) and wrote a three-volume study of the history of the political ideas of Germany from the beginning to the nineteenth century, entitled The Development of the German Public Mind (Hertz 1957/1962/1975), the last volume of which was edited from manuscripts after Frederick Hertz's death in London in 1964.

\section{Karl (Karol) Schlesinger}

Karl Schlesinger was born as Karol Schlesinger into a "Jewish" family in Budapest in 1889. He studied law and economics at the University of Vienna and obtained a doctorate under Böhm-Bawerk in 1914. His dissertation was entitled "Theorie der Geld- und Kreditwirtschaft" (The theory of money and loans) and analysed the role of money in a Walrasian general equilibrium model (Schlesinger 1914). This is remarkable because of the critical attitude of his teachers at the University of Vienna towards both mathematical methods and the general equilibrium approach. Moreover, the integration of money into a general equilibrium framework, although suggested by Walras, had rarely been tackled by mathematical economists at that time.

Schlesinger distinguished between certain and uncertain payments and explained money demand as an insurance against illiquidity. His money demand equation is similar to the famous one developed by Keynes involving the transactions motive and the speculative motive for money demand. According to Morgenstern (1968), Schlesinger was probably the first to use the notion of the "equilibrium rate of interest". ${ }^{3}$ Schumpeter (1954, p. 1082), Patinkin (1965, pp. 576 ff.) and Weintraub (1983, p. 6) also praised Schlesinger's dissertation highly, and part of it was even translated into English (Schlesinger 1959).

\footnotetext{
3 Hayek (1933, p. 139) refers to Schlesinger as the first to introduce this notion into the German literature and prefers it to (Wicksell's) "natural rate of interest".
} 
In 1919 Bela Kun's communist revolution in Hungary led Schlesinger to emigrate to Austria, where he worked as a successful bank manager and became wealthy. He did not occupy any academic position but cultivated his theoretical interests as an active member of the Mises private seminar, the NÖG and the Menger Colloquium. To hone his mathematical abilities, he took private lessons in mathematics from the mathematical economist and statistician Abraham Wald. But the relationship between the two men was more of a collaboration among equals than a pupil-teacher relation.

This collaboration resulted in the birth of one of the most important developments in the history of general equilibrium theory. In his paper "Über die Produktionsgleichungen der ökonomischen Wertlehre" presented to the Menger Colloquium in 1935, Schlesinger considered the problem of the existence of an economic equilibrium in a Walrasian system, realizing that assuring the equality of the numbers of equations and variables is not sufficient to guarantee the existence of an equilibrium (Schlesinger 1935). Instead, inequality conditions have to be taken into account, and non-negativity conditions have to ensure that prices and quantities are positive. Schlesinger encouraged Abraham Wald to deal with the problem, and Wald, John von Neumann and especially Kenneth Arrow and Gerard Debreu provided solutions based on new mathematical instruments.

In addition to his important contributions to pure economic theory, Karl Schlesinger also wrote some papers on more policy-related problems, such as inflation in war times (Schlesinger 1916), the disintegration of the Austro-Hungarian currency (Schlesinger 1920) or French monetary policy (Schlesinger 1931; this paper was presented to the NÖG in October 1930). More could have been expected to come from this highly gifted man, but when the NS army invaded Austria, he committed suicide on March 12, 1938, for fear of persecution. Thus one of the most unusual careers of a brilliant man ended prematurely through the violence of a totalitarian regime.

\section{Concluding remarks}

Even this very brief report on some results of the research project about Austrian economists under the Nazi regime from 1938 to 1945 provides some insights into their diverse fates in that period. The biographies of about 200 economists and their lives during the period of Austria's enforced membership of the Third Reich will appear in Neck (forthcoming). Nearly all of them were affected in some way or another by the politics of the Nazis, in spite of the relatively short period of 1938-1945: some as perpetrators, followers or opportunists, others as victims who were persecuted, forced to emigrate or who even lost their lives. Although generalizations and even a clear-cut division into perpetrators and victims cannot easily be made, and one must also be very careful to avoid moral judgements on individuals' behaviour during those dark times, obtaining some knowledge of the extent to which the totalitarian regime had an impact on their lives may hopefully contribute to strengthening the resistance of current economists against similar political tendencies at present and in the future. 
Acknowledgements Open access funding provided by University of Klagenfurt. The work described in this paper has been funded by the Austrian National Bank (OeNB) Jubiläumsfonds Project No. 16755. The author is indebted to Theodor Venus, Hansjörg Klausinger, Ewald Gottl and Reinhard Linde, to participants at the Annual Meeting 2018 of the Austrian Economic Association, and to two anonymous referees of this journal for helpful information and comments. All shortcomings are his own responsibility.

Open Access This article is distributed under the terms of the Creative Commons Attribution 4.0 International License (http://creativecommons.org/licenses/by/4.0/), which permits unrestricted use, distribution, and reproduction in any medium, provided you give appropriate credit to the original author(s) and the source, provide a link to the Creative Commons license, and indicate if changes were made.

\section{References}

Haberler G (1930) Wirtschaft als Leben. Kritische Bemerkungen zu Gottls methodologischen Schriften. Z Natl 1:28-50

Hayek FA (1933) Monetary theory and the trade cycle. Harcourt Brace, New York. Original: Geldtheorie und Konjunkturtheorie, Hölder Pichler Tempsky, Vienna 1929

Hertz F (1904) Moderne Rassentheorien. Kritische Essays. C.W. Stern, Vienna

Hertz F (1915/1925) Rasse und Kultur: Eine kritische Untersuchung der Rassentheorien. Alfred Kröner, Leipzig (2nd/3rd ed)

Hertz F (1918) Die Produktionsgrundlagen der österreichischen Industrie vor und nach dem Kriege, insbesonders im Vergleich mit Deutschland. Verlag für Fachliteratur, Vienna (several editions)

Hertz F (1921) Ist Österreich wirtschaftlich lebensfähig?. Verband österreichischer Banken und Bankiers, Vienna

Hertz F (1925) Zahlungsbilanz und Lebensfähigkeit Österreichs. Duncker \& Humblot, Munich

Hertz F (1937) Nationalgeist und Politik. Vol. 1: Staatstradition und Nationalismus. Europa-Verlag, Zurich

Hertz F (1944) Nationality in history and politics. A psychology and sociology of national sentiment and nationalism. Routledge \& Kegan Paul, London

Hertz F (1947) The economic problem of the Danubian states. A study in economic nationalism. Victor Gollancz, London

Hertz F (1957/1962/1975) The development of the public mind. A social history of German political sentiments, aspirations and ideas. 3 volumes. George Allen \& Unwin, London

Janssen H (2012) Nationalökonomie und Nationalsozialismus. 4th ed. Metropolis, Marburg (1st ed. 1998)

Morgenstern O (1968) Schlesinger, Karl. In: Sills DL (ed) International encyclopedia of the social sciences, vol 14. Collier-Macmillan, London, pp 51-52

Morikawa T (2001) Handeln, Welt und Wissenschaft. Zur Logik, Erkenntniskritik und Wissenschaftstheorie für Kulturwissenschaften bei Friedrich Gottl und Max Weber. Deutscher Universitäts-Verlag, Wiesbaden

Neck R (ed) (forthcoming) Österreichs Ökonomen und der Nationalsozialismus

Patinkin D (1965) Money, interest and prices. An integration of money and value theory, 2nd edn. Harper \& Row, New York

Rath KW, Predöhl A, Mayer H (1939) Die Wendung zur Volkswirtschaft als Aufgabe volkswirtschaftlicher Theorie. Weltwirtschaftliches Archiv 50:378-434

Robbins L (1971) Autobiography of an economist. Macmillan, London

Schlesinger K (1914) Theorie der Geld- und Kreditwirtschaft. Duncker \& Humblot, Munich

Schlesinger K (1916) Die Veränderungen des Geldwertes im Kriege. Zeitschrift für Volkswirtschaft, Sozialpolitik und Verwaltung

Schlesinger K (1920) The disintegration of the Austro-Hungarian currency. Econ J 30:26-38

Schlesinger K (1931) Das „Rätsel“der französischen Geldpolitik. Z Natl 2:387-407

Schlesinger K (1935) Über die Produktionsgleichungen der ökonomischen Wertlehre. In: Menger K (ed) Ergebnisse eines mathematischen Kolloquiums 6:10-11, Reprint. Springer, Vienna

Schlesinger K (1959) Basic principles of the money economy. Int Econ Pap 9:20-38

Schumpeter JA (1954) History of economic analysis. Allen \& Unwin, London 
Siegfried K-J (1974) Universalismus und Faschismus. Das Gesellschaftsbild Othmar Spanns. Zur politischen Funktion seiner Gesellschaftslehre und Ständestaatskonzeption. Europaverlag, Vienna

von Gottl-Ottlilienfeld F (1901) Die Herrschaft des Wortes. Untersuchungen zur Kritik des nationalökonomischen Denkens. Gustav Fischer, Jena

von Gottl-Ottlilienfeld F (1923) Die wirtschaftliche Dimension. Eine Abrechnung mit der sterbenden Wertlehre. Gustav Fischer, Jena

von Gottl-Ottlilienfeld F (1934a) Die Läuterung des nationalökonomischen Denkens als deutsche Aufgabe. Junker und Dünnhaupt, Berlin

von Gottl-Ottlilienfeld F (1934b) Zeitfragen der Wirtschaft. Über Bolschewismus, Autarkie und deutschen Sozialismus. Junker und Dünnhaupt, Berlin

von Gottl-Ottlilienfeld F (1940) Wirtschaft als Wissen, Tat und Wehr. Über Volkswirtschaftslehre, Autarkie und Wehrwirtschaft. Junker und Dünnhaupt, Berlin

Weintraub ER (1983) On the existence of a competitive equilibrium: 1930-1954. J Econ Lit 21:1-39

Publisher's Note Springer Nature remains neutral with regard to jurisdictional claims in published maps and institutional affiliations. 